\title{
Risiko Sebaran Bencana Non-Alam (Covid-19) dalam Pola Ruang Kewilayahan di Kabupaten Wonosobo
}

\author{
Visilya Faniza, Holi Bina Wijaya, Zukruf Novandaya \\ Pusat Pelayanan Perencanaan Pembangunan Parisipatif, Universitas Diponegoro, Semarang \\ e-mail:p5undip@yahoo.co.id
}

\begin{abstract}
Abstrak-Covid-19 menjadi pandemi global karena persebarannya yang cepat dan hampir menjangkau semua negara. Indonesia memiliki jumlah penduduk ke-empat terbanyak di dunia memiliki potensi kerawanan yang tinggi terhadap Covid-19. Pandemi Covid-19 ini termasuk dalam kategori bencana non-alam dan merupakan hal baru yang dihadapi Indonesia. Persebaran Covid-19 yang cepat dan keterkaitan antar wilayah yang kuat khususnya di Pulau Jawa yang merupakan pulau dengan jumlah penduduk terpadat di Indonesia. Kasus tersebut tidak hanya berada di kawasan perkotaan (urban), tetapi juga wilayah yang didominasi rural seperti Kabupaten Wonosobo. Persebaran Covid-19 secara transmisi lokal maupun perjalanan erat kaitannya dengan pola ruang suatu kawasan. Kawasan rural dan peri-urban memiliki pusat-pusat keramaian yang berpotensi tinggi menjadi titik penyebaran virus Covid-19 meski kepadatan tempat tinggal tidak setinggi kawasan perkotaan. Karakteristik kultural masyarakat rural yang memiliki kegiatan sosial yang tinggi untuk mempererat silaturahmi dapat memperluas atau membuat titik-titik penyebaran baru. Hasil dari studi ini adalah analisis kaitan risiko bencana pandemi Covid-19 terhadap pola ruang fisik dan sosial di Kabupaten Wonosobo. Hasil tersebut mengarahkan pada rekomendasi terkait pembatasan kegiatan di wilayah dengan resiko tertinggi guna mengurangi laju penyebaran virus Covid-19 di Kabupaten Wonosobo.
\end{abstract}

Kata Kunci- pandemi Covid-19, pola ruang wilayah, risiko bencana non-alam

\section{PENDAHULUAN}

$C$ oronavirus disease 2019 (Covid-19), yang pertama kali dilaporkan di Wuhan, Tiongkok pada 31 Desember 2019, adalah penyakit yang berasal dari virus corona jenis SARSCoV-2 [1]. Dalam dua bulan pertama kasus penyebaran di Tiongkok menyebabkan berbagai macam demam, namun terdapat pula pasien yang tidak mengalami demam dan tidak dijumpai keanehan dalam hasil radiologi [2]. Berdasarkan laman indonesia.go.id di Indonesia kasus Covid-19 pertama ada pada dua WNI yang berdomisili di Depok pada 2 Maret 2020. Kasus Covid-19 pertama ini menjangkit ibu dan anak berusia 64 dan 31 tahun. Dua WNI ini tertular oleh WNA asal Jepang yang berkunjung ke Indonesia. Kasus Covid-19 di Indonesia hingga 14 November 2020 yang tercatat di laman covid19.go.id mencapai 463.007 kasus positif, 338.094 sembuh, dan 15.148 meninggal. Kasus terbanyak yang ada di Indoneisa berasal dari provinsi DKI Jakarta dengan 116.207 kasus atau 25,4\% dari total kasus di Indonesia. Daerah lain yang memiliki jumlah kasus terbanyak kedua adalah provinsi Jawa Timur dengan 55.814 kasus atau 12,2\% dari total kasus di Indonesia.

Jawa Tengah sendiri berada di urutan keempat dalam jumlah kasus Covid-19 di Indonesia. Jumlah kasus yang ada di Jawa Tengah mencapai 41.150 kasus atau 9\% dari jumlah kasus di Indonesia. Jumlah ini sedikit lebih rendah dari provinsi Jawa Barat yang memiliki 43.373 kasus atau 9,5\% dari jumlah kasus di Indoensia. Penyebaran lebih tinggi di wilayah perkotaan dibandingkan wilayah rural $[3,4]$ Penyebaran di wilayah perkotaan lebih tinggi jika dibandingkan dengan wilayah rural.

Kabupaten Wonosobo dengan luas $984.68 \mathrm{~km}^{2}$ dan terbagi atas 15 kecamatan. Kecamatan Wadaslintang yang terluas memiliki $127.15 \mathrm{~km}^{2}$ dan Kecamatan Wonosobo yang paling kecil memiliki $32,38 \mathrm{~km}^{2}$. Kabupaten Wonosobo memiliki jumlah penduduk sebanyak 790.491 jiwa dengan laju pertumbuhan penduduk sebesar $0,40 \%$. Kepadatan penduduk tertinggi adalah kecamatan Wonosobo dengan $2.793 \mathrm{jiwa} / \mathrm{km}^{2}$. Angka tersebut lebih tinggi dibanding rata-rata kepadatan penduduk Kabupaten Wonosobo yang hanya 803 jiwa $/ \mathrm{km}^{2}$. Visualiasasi kepadatan penduduk pada Gambar 1.

Kawasan rural dan peri-urban seperti Kabupaten Wonosobo memiliki pusat-pusat keramaian yang berpotensi tinggi menjadi titik penyebaran virus Covid-19 meski kepadatan tempat tinggal tidak setinggi kawasan perkotaan. Penyebaran kasus Covid-19 lebih banyak terjadi di wilayah yang memiliki jaringan sosial yang kuat. Jaringan sosial yang kuat membuat masyarakat berkegiatan bersama. Kegiatan masyarakat tersebut menjadi salah satu penyebab penyebaran Covid-19 [5]. Kepadatan penduduk berpengaruh juga terhadap penyebaran Covid-19. Wilayah kepadatan tinggi memiliki tingkat penyebaran lebih tinggi dibandingkan dengan wilayah kepadatan rendah [4].

Adanya bahaya (hazard) bencana pandemi Covid-19, maka diperlukan adanya pembahasan keterkaitan antara keruangan wilayah dalam upaya mengurangi persebaran virus Covid-19. Penelitian ini bertujuan untuk menganalisis risiko bencana non alam (Covid-19) di Kabupaten Wonosobo dari segi keruangan. Hal ini dilakukan guna mengetahui hubungan antara kondisi fisik dan sosial dengan angka kasus Covid-19 yang terjadi. 


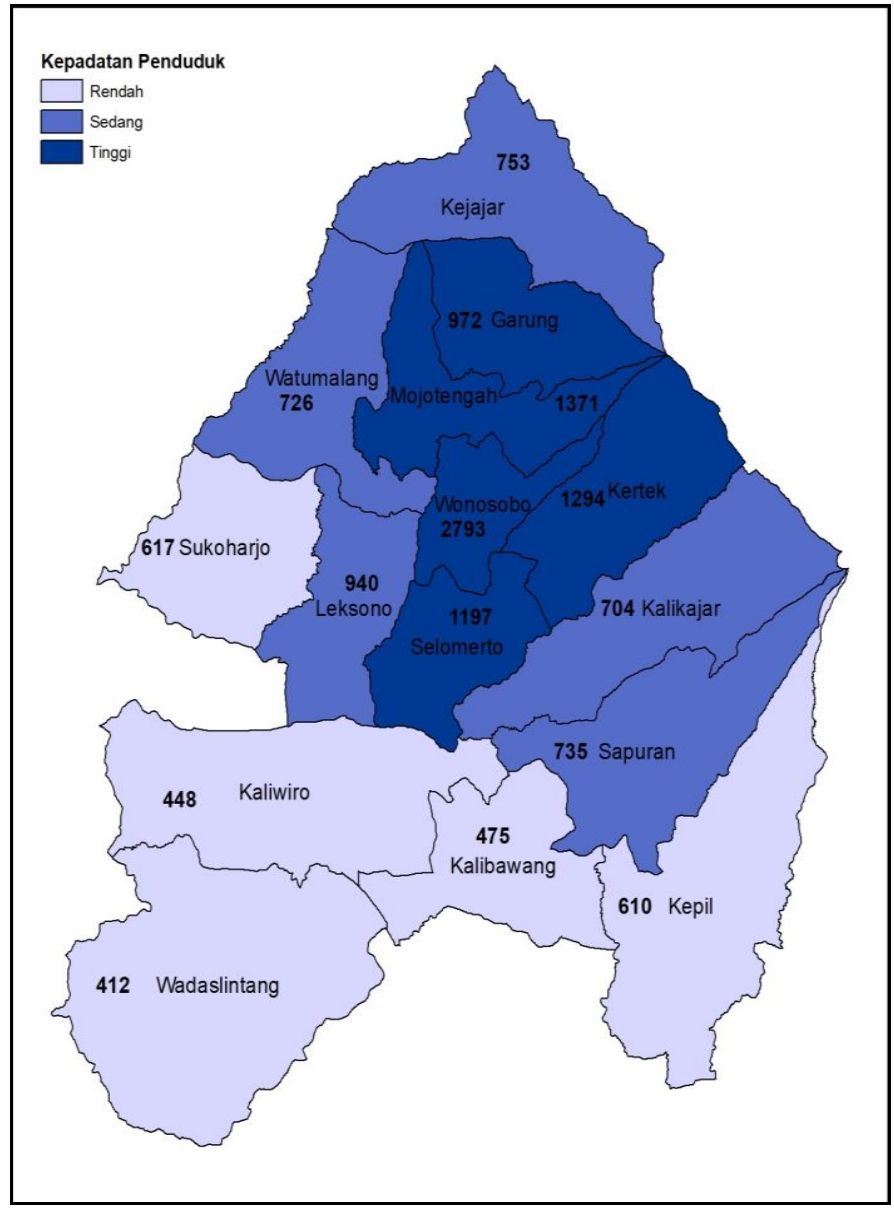

Gambar 1. Peta Kepadatan Penduduk Kabupaten Wonosobo

\section{URAIAN PENELITIAN}

\section{A. Metodologi}

Metodologi penelitian menggunakan analisis spasial dan sosial masyarakat di Kabupaten Wonosobo. Menggunakan data kasus Covid-19 hingga November 2020 yang diambil dari laman covid.go.id, data guna lahan, demografi, serta sosial dan budaya masyarakat yang didapat dari IKUPD 2020 Kabupaten Wonosobo. Informasi lebih jelas mengenai alur metode penelitian pada Gambar 2..

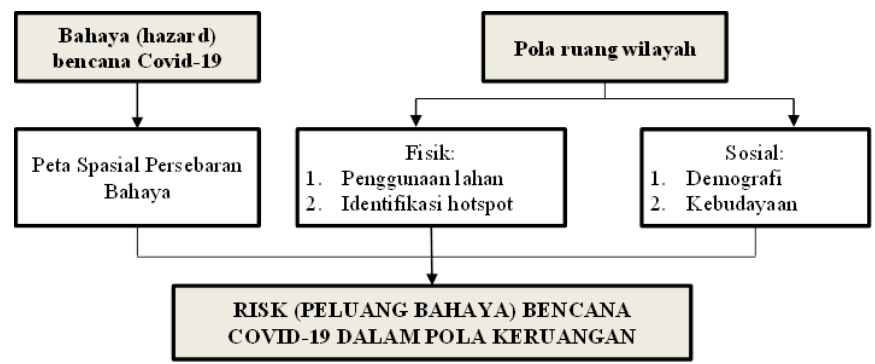

Gambar 2. Kerangka penelitian pada risiko bencana pandemi Covid-19 dalam pola keruangan wilayah

Variabel pertama dalam penelitian ini adalah bahaya (hazard) dan pola ruang wilayah. Bahaya (hazard) yang dimaksud adalah probabilitas suatu kejadian bencana yang terjadi di suatu wilayah dalam rentang waktu tertentu [6]. Dalam studi kasus ini bencana yang dihadapi adalah pandemi
Covid-19 yang termasuk dalam kategori bencana non-alam. Sementara pada variabel pola ruang wilayah terbagi atas fisik (penggunaan lahan dan kluster penyebaran) dan sosial (demografi dan kebudayaan).

Analisis spasial berupa analisis overlay digunakan untuk mengidentifikasi persebaran hazard dengan pola ruang wilayah secara fisik. Data yang diproses menggunakan teknik overlay adalah data guna lahan dan sebaran Covid-19. Sementara kajian sosial yaitu demografi dan kebudayaan mendukung dan memperjelas fenomena yang diperlihatkan oleh hasil identifikasi spasial tersebut. Penelitian ini menghasilkan risiko (peluang bahaya) bencana Covid-19 dalam bentuk pola keruangan wilayah. Hasil tersebut kemudian menjadi dasar penyusunan rekomendasi secara pola keruangan untuk mengurangi laju transmisi virus Covid-19.

\section{B. Hasil dan Pembahasan}

Persebaran Covid-19 secara transmisi lokal maupun perjalanan erat kaitannya dengan pola ruang suatu kawasan. Jumlah kasus yang ada di Wonosobo berdasarkan laman corona.wonosobokab.go.id mencapai 2.125 kasus positif dengan 1.182 sembuh dan 112 meninggal. Peta risiko yang dirilis oleh laman covid19.go.id menunjukkan Wonosobo memiliki risiko sedang dalam kasus Covid-19 ini [7].

Berdasarkan data Covid-19 Kabupaten Wonosobo, wilayah yang dengan kasus aktif terbanyak adalah Kecamatan Wonosobo. Kecamatan Wonosobo merupakan kecamatan dengan wilayah terkecil, namun memiliki kepadatan penduduk terbesar. Selain itu, wilayah ini juga memiliki karakteristik peri-urban dimana pusat kegiatan cukup ramai di Kecamatan Wonosobo. Hal ini menunjukan bahwa Kecamatan Wonosobo adalah hotspot makro di wilayah Kabupaten Wonosobo.

Kecamatan Wonosobo memiliki kasus aktif tertinggi di Kabupaten Wonosobo yaitu sebesar 41 kasus. Sementara Kecamatan Sukoharjo dan Kalijakar merupakan kecamatan dengan kasus aktif tertinggi kedua sebesar 21 kasus di masingmasing kecamatan. Kecamatan Garung dan Kertek yang terletak tidak jauh dari hotspot Kecamatan Wonosobo masingmasing memiliki 12 kasus. Wilayah lainnya yang memiliki angka kasus aktif yang rendah $(1,2)$ adalah Kecamatan Kalibawang, Kepil, Kaliwiro, dan Wadaslintang.

Tabel 1. Jumlah Kasus Aktif dan Kepadatan Penduduk Kabupaten Wonosobo

\begin{tabular}{clcc}
\hline \hline No & Nama Kecamatan & Jumlah Kasus Aktif & $\begin{array}{c}\text { Kepadatan } \\
\text { Penduduk } \\
\text { (per km } \mathbf{~}^{\mathbf{2}}\end{array}$ \\
\hline 1 & Kalibawang & 1 & 475 \\
2 & Kepil & 1 & 610 \\
3 & Kaliwiro & 2 & 448 \\
4 & Wadaslintang & 2 & 412 \\
5 & Sapuran & 3 & 735 \\
6 & Leksono & 5 & 940 \\
7 & Watumalang & 5 & 726 \\
8 & Mojotengah & 6 & 1371 \\
9 & Kejajar & 9 & 753 \\
10 & Selomerto & 11 & 1197 \\
11 & Garung & 12 & 972 \\
12 & Kertek & 12 & 1294 \\
13 & Kalikajar & 21 & 704 \\
14 & Sukoharjo & 21 & 617 \\
15 & Wonosobo & 41 & 2793 \\
\hline \hline
\end{tabular}


Kabupaten Wonosobo menunjukan karakteristik wilayah pedesaan dengan dominasi penggunaan lahan untuk kegiatan pertanian dan perhutanan. Wilayah ini juga memiliki pusat wilayah yang memiliki karakter peri-urban dimana kegiatan pusat dilaksanakan di wilayah ini. Terlihat pada peta penggunaan lahan Kabupaten Wonosobo menunjukan bahwa Kecamatan Wonosobo dan kecamatan lain disekitarnya merupakan wilayah dengan luas permukiman yang cukup tinggi. Informasi penggunaan lahan dapat dilihat pada gambar dan tabel berikut.

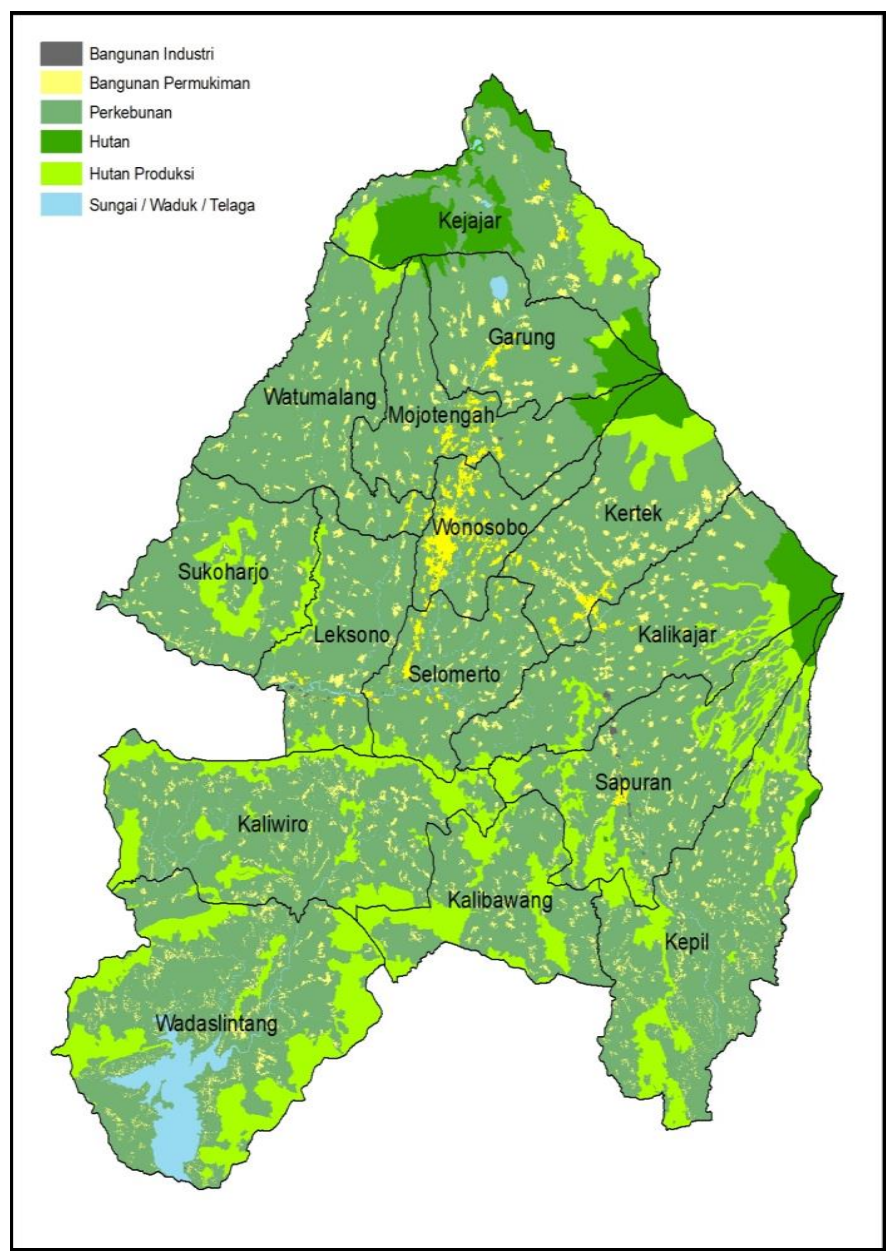

Gambar 3. Penggunaan lahan Kabupaten Wonosobo

Tabel 2. Luas Permukiman di Kabupaten Wonosobo

\begin{tabular}{clc}
\hline \hline No & Kecamatan & Luas Permukiman $\left.\mathbf{( k m}^{\mathbf{2}}\right)$ \\
\hline 1 & Kalibawang & 2.35 \\
2 & Kejajar & 2.36 \\
3 & Sukoharjo & 2.50 \\
4 & Garung & 2.79 \\
5 & Leksono & 3.10 \\
6 & Watumalang & 3.30 \\
7 & Selomerto & 3.49 \\
8 & Mojotengah & 3.83 \\
9 & Sapuran & 4.28 \\
10 & Kalikajar & 4.43 \\
11 & Kaliwiro & 4.92 \\
12 & Kepil & 5.37 \\
13 & Kertek & 5.62 \\
14 & Wadaslintang & 6.04 \\
15 & Wonosobo & 6.08 \\
\hline \hline
\end{tabular}

Persebaran kasus aktif terpusat pada wilayah utara Kabupaten Wonosobo. Hal ini disebabkan oleh pergerakan transportasi dan kegiatan masyarakat terpusat pada Kecamatan Wonosobo dan sekitarnya. Sementara wilayah selatan Kabupaten Wonosobo menunjukan penggunaan lahan yang dominan dengan perkebunan dan hutan. Peta sebaran kasus aktif Covid-19 Kabupaten Wonosobo pada Gambar 4.

Peta pada Gambar 4 menunjukan Perkembangan klasterisasi penyebaran virus Covid-19 banyak dilaporkan berasal dari masyarakat yang berpergian ke luar wilayah dan kembali. Hal ini juga terjadi di Kabupaten Wonosobo dimana klaster perkantoran dan permukiman dilaporkan sebagai wilayah mikro dengan jumlah kasus yang tinggi. Lokasi perkantoran dan permukiman padat penduduk di sekitar Kecamatan Wonosobo mendukung asumsi bahwa wilayah ini merupakan titik penyebaran di Kabupaten Wonosobo.

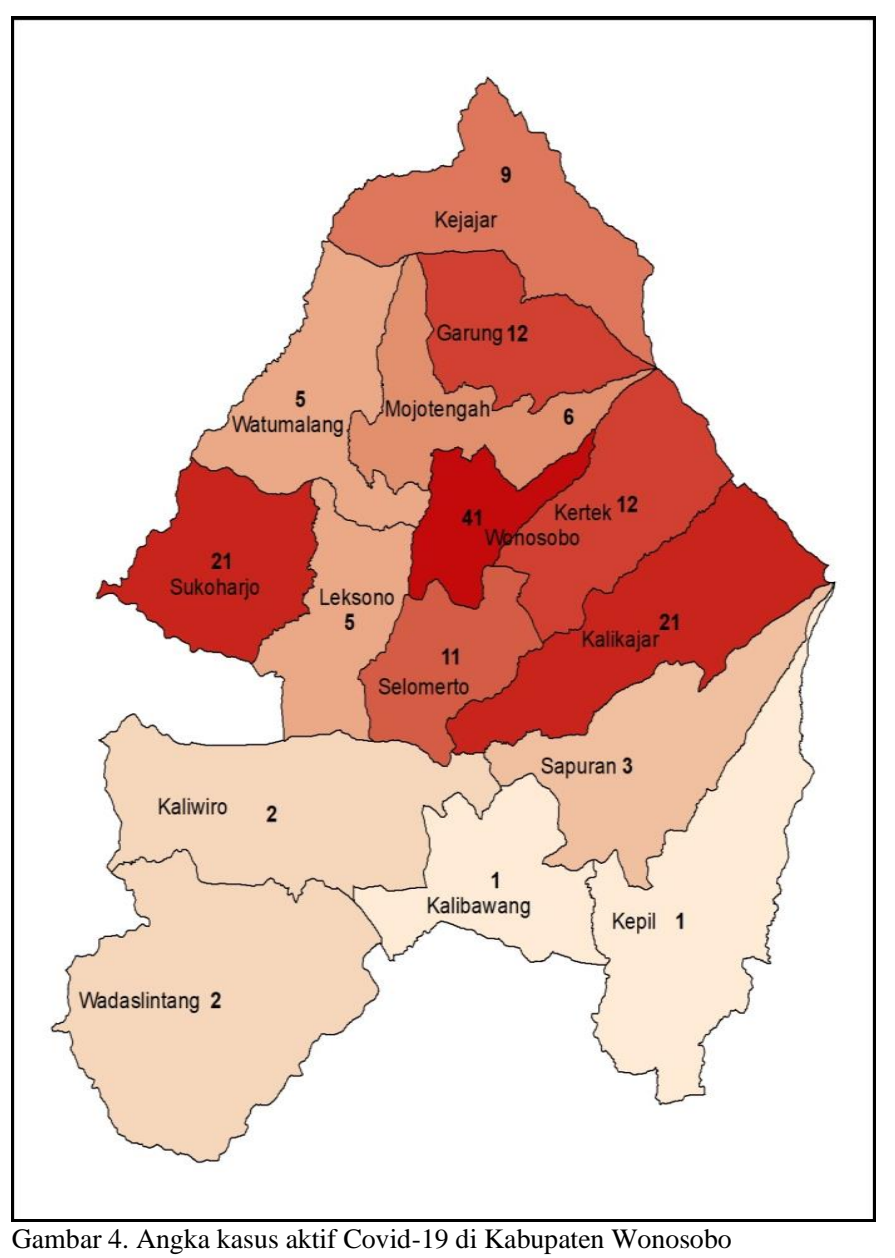

Analisis spasial pemetaan pola ruang fisik dan sebaran kasus aktif tersebut memberikan kesimpulan bahwa wilayah dengan dominasi penggunaan lahan permukiman peri-urban, permukiman desa, serta perindustrian dan perkantoran merupakan hotspot yang menjadikan wilayah tersebut memiliki kerentanan yang tinggi. Tumpang susun (overlay) antara peta penggunaan lahan hotspot dengan peta kasus aktif akan menunjukan lebih jelas keterkaitan antara pola ruang fisik dengan perkembangan kasus aktif Covid-19. Peta tersebut dapat dilihat pada Gambar 5. 
Masyarakat di Kabupaten Wonosobo memiliki kecenderungan partisipatif dalam aksi bersama dan kegiatan masyarakat. Seperti wilayah suburban lainnya, Kabupaten Wonosobo masih memiliki karakteristik gotong royong kuat. Karakteristik ini juga yang turut meningkatkan risiko penyebaran Covid-19 di Kabupaten Wonosobo. Karakteristik gotong royong mengharuskan masyarakat untuk berkumpul secara sosial sehingga wilayah dengan kepadatan lebih tinggi di Wonosobo memiliki risiko penyebaran Covid-19 yang lebih tinggi [8]. Karakteristik kultural masyarakat rural yang memiliki kegiatan sosial yang tinggi untuk mempererat silaturahmi dapat memperluas atau membuat klaster penyebaran (hotspots) baru.

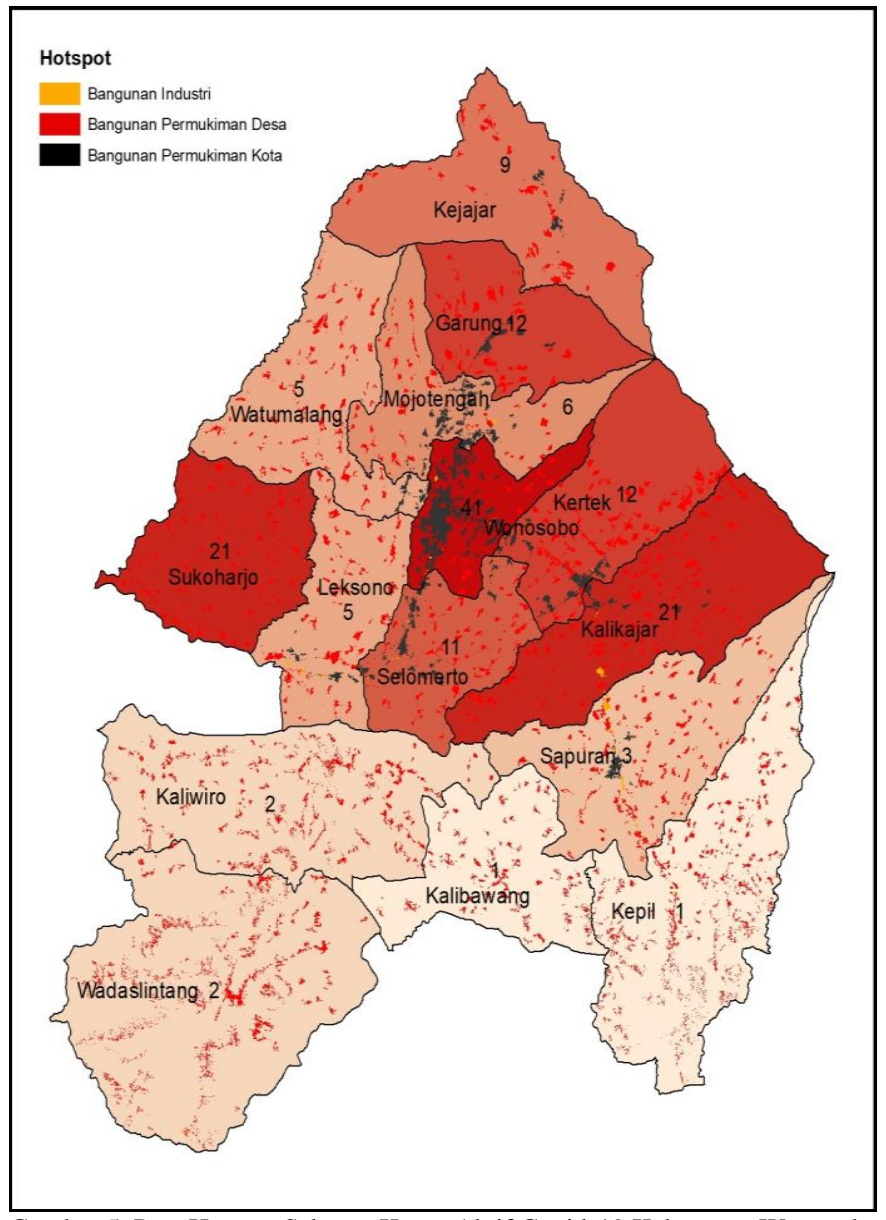

Gambar 5. Peta Hotspot Sebaran Kasus Aktif Covid-19 Kabupaten Wonosobo

Budaya gotong royong sudah ada di Indonesia sejak lama. Gotong royong dalam menghadapi bencana pandemi Covid-19 ini dapat diimplementasikan dalam beberapa hal seperti pengaturan bersama kegiatan-kegiatan bermasyarakat dengan protokol kesehatan [9]. Gotong royong juga dinilai mampu menjaga kesadaran kolektif yang hidup di masyarakat [10]. Oleh karena itu semakin tinggi angka gotong royong, maka semakin tinggi pula kesadaran kolektif yang ada di masyarakat. Hal ini berimplikasi pada kemampuan masyarakat untuk membantu masyarakat yang lainnya di masa yang sulit sekalipun seperti bencana pandemi Covid-19 ini. Kegiatan gotong royong juga terbukti mampu membantu masyarakat dalam menghadapi pandemi yaitu melalui kegiatan kolektif masyarakat [11]. Namun dari semua itu tetap perlu diperhatikan interaksi sosial yang bisa memicu penyebaran Covid-19.

Tabel 3. Perhitungan Variabel Gotong Royong di Kabupaten Wonosobo

\begin{tabular}{|c|c|c|c|}
\hline $\begin{array}{c}\text { Variabel dan Sub-Variabel } \\
\text { Turunan }\end{array}$ & $\begin{array}{c}\text { Nilai } \\
\text { Likert }\end{array}$ & $\begin{array}{c}\text { Nilai } \\
\text { Persen }\end{array}$ & Interpretasi \\
\hline Gotong Royong & 3.99 & $79.80 \%$ & Baik \\
\hline $\begin{array}{l}\text { 1. Jejaring Sosial } \\
\text { a. Partisipasi dalam }\end{array}$ & 3.93 & $78.60 \%$ & Baik \\
\hline $\begin{array}{l}\text { Pertemuan Warga di } \\
\text { Lingkungan Tempat } \\
\text { tinggal }\end{array}$ & 4.06 & $81.20 \%$ & Baik \\
\hline $\begin{array}{l}\text { b. Keanggotaan dalam } \\
\text { kelompok/ organisasi } \\
\text { lingkungan tempat tinggal }\end{array}$ & 3.79 & $75.80 \%$ & Baik \\
\hline 2. Aksi Bersama & 4.16 & $83.20 \%$ & Baik \\
\hline a. Resiprositas & 4.14 & $82.80 \%$ & Baik \\
\hline $\begin{array}{l}\text { 1) Kesediaan membantu } \\
\text { tetangga }\end{array}$ & 4.74 & $94.80 \%$ & Sangat Baik \\
\hline $\begin{array}{l}\text { 2)Persepsi kemudahan } \\
\text { mendapat pertolongan } \\
\text { keuangan di lingkungan } \\
\text { tempat tinggal }\end{array}$ & 3.54 & $70.80 \%$ & Baik \\
\hline $\begin{array}{l}\text { 3. Aksi bersama } \\
\text { a.Partisipasi rumah tangga } \\
\text { dalam aksi bersama di } \\
\text { lingkungan } \\
\end{array}$ & 4.18 & $83.60 \%$ & Baik \\
\hline
\end{tabular}

Tingginya angka partisipasi gotong royong kemasyarakatan tidak selalu berdampak buruk. Hal ini ditunjukan pada kajian Indeks Kinerja Utama Kabupaten Wonosobo dimana pada sub-variabel ketersediaan membantu tetangga memiliki nilai yang cukup tinggi. Kegiatan gotong royong ini juga akan mampu meringankan masyarakat yang kurang mampu dalam menghadapi risiko bencana pandemi Covid-19 di Kabupaten Wonosobo. Selain itu, masyarakat Kabupaten Wonosobo cukup aktif dalam partisipasi pengambilan keputusan bersama dengan pemerintah sehingga dapat disimpulkan bahwa masyarakat memiliki kepedulian terhadap usaha menanggulangi bencana pandemi Covid-19 ini [8].

\section{KESIMPULAN}

Sebaran bencana non-alam (Covid-19) di Kabupaten Wonosobo berkaitan erat dengan pola ruang kewilayahan baik secara fisik maupun sosial. Secara fisik wilayah yang memiliki kepadatan penduduk tinggi lebih berisiko dibandingkan dengan yang memiliki kepadatan penduduk rendah. Selain itu dilihat dari penggunaan lahannya, pasar, rumah tangga, perkantoran, industri, dan tempat wisata menjadi hotspot mikro pada kawasan tertentu. Tingginya aktivitas masyarakat terutama di wilayah yang menjadi pusat kegiatan menjadi penyebab tingginya risiko di wilayah berkepadatan tinggi. Hal ini menunjukkan diperlukannya pencegahan yang lebih intensif di wilayah yang memiliki kepadatan penduduk tinggi. Selain dilihat dari aspek fisik, aspek sosial Kabupaten Wonosobo juga menjadi hal yang berkaitan dengan risiko sebaran Covid-19. Tingginya angka partisipasi gotong royong masyarakat memiliki dua sisi, sisi yang satu merupakan hal yang berbahaya di masa pandemi sedangkan sisi lainnya merupakan budaya yang baik dengan saling membantu satu sama lain.

Wilayah di Kabupaten Wonosobo yang menjadi perhatian 
utama adalah Kecamatan Wonosobo dan sekitarnya. Hal ini dikarenakan Kecamatan Wonosobo memiliki hotspot terbanyak dan memiliki kepadatan penduduk yang tinggi. Meski demikian, wilayah selatan yang memiliki risiko rendah juga perlu diperhatikan pencegahannya agar penyebaran Covid-19 tidak semakin meluas. Kerjasama dan partisipasi aktif baik dari pemerintah maupun masyarakat diperlukan untuk meningkatkan efektivitas pencegahan penyebaran Covid-19. Selain itu, dibutuhkan adanya pembangunan masyarakat tangguh bencana untuk mengatasi permasalahan lain yang timbul akibat bencana non-alam seperti pandemi Covid-19 di masa mendatang.

\section{PENGAKUAN}

Data yang digunakan dalam artikel ini berdasar pada kajian Indeks Kinerja Utama Kabupaten Wonosobo tahnun 2020 yang merupakan kerjasama P5 FT UNDIP dengan Pemerintah Daerah Kabupaten Wonosobo.

\section{DAFTAR PUSTAKA}

[1] KEMENKES 2020 Gugus tugas percepatan penanganan covid-19 1 Gugus tugas percepatan penanganan covid-19 1-39

[2] Guan W, Ni Z, Hu Y, Liang W, Ou C, He J, Liu L, Shan H, Lei C, Hui D S C, Du B, Li L, Zeng G, Yuen K Y, Chen R, Tang C, Wang T, Chen P, Xiang J, Li S, Wang J L, Liang Z, Peng Y, Wei L, Liu Y, Hu Y H, Peng P, Wang J M, Liu J, Chen Z, Li G, Zheng Z, Qiu S, Luo J, Ye C, Zhu S and Zhong N 2020 Clinical characteristics of coronavirus disease 2019 in China N. Engl. J. Med. 382 1708-20

[3] Andersen L M, Harden S R, Sugg M M, Runkle J D and Lundquist T E 2021 Analyzing the spatial determinants of local Covid-19 transmission in the United States Sci. Total Environ. 754142396

[4] Paul R, Arif A A, Adeyemi O, Ghosh S and Han D 2020 Progression of COVID-19 From Urban to Rural Areas in the United States: A Spatiotemporal Analysis of Prevalence Rates J. Rural Heal. 36 591-601

[5] Kuchler T, Russel D and Stroebel J 2020 The geographic spread of COVID-19 correlates with the structure of social networks as measured by Facebook

[6] Badan Nasional Penanggulangan Bencana 2012 Pedoman Umum Pengkajian Risiko Bencana (Indonesia)

[7] Satuan Tugas Penanganan Covid-19 Kab. Wonosobo 2020 Pusat Informasi Covid-19 Kabupaten Wonosobo Pus. Inf. Covid-19 Kabupaten Wonosobo

[8] P5 FT UNDIP 2020 Kajian Indeks Kinerja Utama Kabupaten Wonosobo 2020

[9] Yasa I W P 2020 Tri Hita Karana untuk Pencegahan COVID-19 di Bali J. Socius J. Sociol. Res. Educ. 754

[10] Alimin Alwi 2020 Solidaritas Masyarakat Multikultural dalam Menghadapi Covid-19 Pros. Semin. Nas. Probl. Sos. Pandemi COVID-19 "Membangun Optimisme di Teng. Pandemi Covid-19 33-6

[11] Juanda A, Kurniawan P, Suwanto S, Eka P D and Astutik E P 2020 Menumbuhkan Rasa Gotong Royong Dan Interaksi Sosial Di Kelurahan Pondok Jaya Kota Tangerang Selatan Dedik. PKM 113 